\title{
Induction and Release of Bud Dormancy in Woody Perennials: A Science Comes of Age
}

\author{
Rajeev Arora ${ }^{1}$ \\ Department of Horticulture, Iowa State University, Ames, IA 50011 \\ Lisa J. Rowland \\ U.S. Department of Agriculture-Agricultural Research Service, Fruit Laboratory, Beltsville, MD 20705 \\ Karen Tanino \\ Department of Plant Sciences, University of Saskatchewan, Saskatoon, SK, Canada, S7N 5A8
}

\begin{abstract}
The path to dormancy induction, maintenance, and release is a continuum and has been the topic of thousands of research articles to date. It would be an impossible task and indeed presumptuous of us to imagine that we could review all the research conducted on dormancy in the past century in this article. The multiple and complex nature of the dormancy phenomenon would require not one review but a series of in-depth reviews to cover the research on individual subdisciplines that come under the umbrella of dormancy. Its complexity and multiplicity of various subdisciplines stem from the fact that dormancy affects diverse plant structures (buds, seeds, bulbs, etc.) distinctly and that these dormant structures maintain distinct anatomical and physiological relations with neighboring parts. We, therefore, have chosen to discuss here only one, nevertheless highly significant, aspect of dormancy, i.e., bud dormancy in woody plants.
\end{abstract}

As one reflects over nearly a century of work, it is apparent that, as with other disciplines, dormancy research has evolved as different aspects of bud dormancy (e.g., site of dormancy; photoperiod and environmental induction of dormancy; physiology of dormancy control, particularly phytohormones; chilling requirement-effective temperatures, bud differences, modification of chilling requirement by environment and/or cultural practices, models for calculating chilling requirement; dormancy-breaking chemicals and/or stress treatments) catching the fancy of horticulturists at different periods on the temporal curve of dormancy research. This research was extensively reviewed during the 1950s and 1960s (Doorenbos,1953; Leike, 1965; Romberger,1963; Samish, 1954; Vegis, 1964; Wareing, 1956, 1969), followed by more recent reviews and workshop proceedings in the 1970s, 1980s, and 1990s (Champagnat, 1989; Dennis, 1987; Erez and Lavee, 1974; Faust et al., 1997; Fuchigami and Nee, 1987; Kaurin et al., 1985; Lang, 1987, 1994; Nooden and Weber, 1978; Perry, 1971; Rowland and Arora, 1997; Saunders, 1978; Saure, 1985; Weiser, 1970; among others). To appreciate the continuity of significant research developments in this field, we recommend them as a must-read for students of plant dormancy.

Although many significant mileposts have been reached in our understanding of the induction and release of bud dormancy in the past 50 to 60 years (reviewed in the above citations), research published up until the 1980s includes little information on experimental systems and approaches for studying the genetics of bud dormancy and the cellular and molecular events - gene expression and regulation, signaling mechanism(s), or mechanistic aspects - associated with regulation of bud dormancy. Many of us must wonder how H. Muller-Thurgau had already confirmed in 1885 that a shortened growth period of the shoots caused by water stress promotes early inception of bud dormancy and shortens its duration, i.e., reduces the chilling requirement. This observation was further supported by Chandler and Tufts in 1934 based on their observation that an extended growth period of shoots delays budbreak the following spring if there is insufficient chilling. Despite these early observations, today we still do not clearly understand the cellular biology of how environmental stress regulates bud dormancy.

Perhaps the slow progress in our understanding of the basic biology of

This journal paper of the Iowa Agriculture and Home Economics Experiment Station, Ames, Iowa, Project 3601 was supported by Hatch Act and State of Iowa funds.

${ }^{1}$ To whom reprint requests should be addressed; e-mail rarora@iastate.edu. dormancy induction and release in the past century has been, in part, due to the preoccupation with the linear hormonal hypothesis, i.e., dormancy is induced and broken by changes in the balance between inhibiting and stimulating endogenous substances. Another area that received much attention in the past (particularly during the 1970s and 1980s) was the search for chemical treatments to break bud dormancy in fruit crops. Whereas this work has had a significant impact on economic production of temperate fruit and their distribution in subtropical regions that are responsible for the world's early market production, until recently not much attention was paid to the molecular mechanism(s) and regulatory pathways involved in chemical-induced breaking of dormancy. Thankfully, that all seems to be changing, and interest in the basic biology of bud dormancy has mushroomed in recent years as indicated by a series of reports published in the proceedings for the two international symposia on plant dormancy in 1995 (in Corvallis, Ore.) (Lang, 1996) and 2000 (in Angers, France) (Viémont and Crabbé, 2000) and in other recent papers (reviewed in the following sections). Because most advancements regarding the mechanistic aspects of bud-dormancy induction and release at the subcellular level (e.g., biochemical pathways and signals, cell-to-cell communication at shoot apices, physiological separation of dormancy from cold acclimation, biochemistry of dormancy mutants, hormonal physiology) and the genetics of dormancy in woody plants (identification of QTLs for dormancy-determining traits, mapping of dormancy-related genes, gene action of dormancy, etc.) have only been made in the last 10 to 20 years, we have primarily focused our discussion on these topics as they relate to our increased understanding of bud-dormancy regulation in woody perennials. For the discussion of dormancy that follows, we have chosen to use the newer terminology of Lang et al. (1987) to describe the different stages of bud dormancy because it is more physiologically descriptive than most of the older terminology. However, for those readers that are more familiar with the older terminology, we have given the commonly used terms in Doorenbos (1953) and Samish (1954), in parenthesis, following the first use of the newer terms.

\section{DELINKING SEASONAL TRANSITIONS IN BUD DORMANCY AND COLD HARDINESS: SYSTEMS AND APPROACHES}

Although considerable progress has been achieved, large functional gaps of knowledge still exist in bud-dormancy induction research. The fundamental problem involves separating dormancy processes from those functions important to freezing and dehydration tolerance as well as distinguishing cause versus effect. Woody perennials of the temperate zone are exposed to freezing temperatures each winter. Their ability to survive depends on an evolved mechanism by which plants enter a state of dormancy and also develop cold hardiness, i.e., cold accclimation in the fall (Powell, 1987). The two environmental cues that induce the shift from paradormancy (summer dormancy or correlative inhibition) to endodormancy (winter dormancy or rest) in buds and simultaneously initiate cold acclimation are 1) increasingly shorter photoperiods and 2) colder temperatures. During winter months, while buds are fully endodormant and then ecodormant (imposed dormancy or quiescence), plant tissues are also maximally hardy (Nissila and Fuchigami, 1978). Upon the return of warmer temperatures in spring, these changes culminate in the release from dormancy and also fully 
dehardened plants. Thus, a continuum of the onset and release of bud dormancy in a woody plant's annual growth cycle (Fuchigami et al., 1982) is superimposed on a seasonal development and loss of cold hardiness. This renders it difficult to distinguish physiological and molecular changes associated with dormancy regulation from those underlying the seasonality of cold hardiness. However, researchers have used various systems and strategies to delink these two events physiologically and study them independently of each other. Following is a brief description of some of these approaches.

USE OF SIBLING DECIDUOUS AND EVERGREEN GENOTYPES. One of the first attempts to study protein changes associated specifically with the changes in dormancy or cold hardiness in a woody plant was through the use of genetically related peach (Prunus persica) genotypes segregating for deciduous and evergreen habits (Arora et al., 1992). Comparative analyses of the seasonality and the degree of cold hardiness with that of protein changes in the two genotypes (only one lacking endodormancy but both exhibiting cold acclimation) enabled these researchers to associate certain protein and gene-expression changes specifically with cold acclimation and others with endodormancy transitions (Arora et al., 1992; Arora and Wisniewski, 1994; Artlip et al., 1997).

DIFFERENTIAL INDUCTION OF DORMANCY AND COLD ACCLIMATION. Fennell and Hoover (1991) showed that Vitis labruscana is able to enter endodormancy fully in response to short photoperiods without coldacclimating. Using controlled-environment treatments, Salzman et al. (1996) exploited this system to characterize differential expression of proteins in grape buds during the normally superimposed endodormancy and cold acclimation programs (in response to short photoperiods and cold treatment) and in the buds that had been exposed to only the endodormancy program (use of only short photoperiods). This enabled researchers to identify gene products specific to the development of dormancy or to cold acclimation.

DiFFERENTIAL REgULATION OF CHILl-UNIT ACCUMULATION (CHILLING REQUIREMENT) AND COLD HARDINESS. Typically, temperatures above or below 0 to $7^{\circ} \mathrm{C}$ are not believed to contribute toward chill-unit accumulation. However, depending on the species and the depth of bud dormancy, temperatures outside of this range may or may not negate chill unit accumulation (Erez and Couvillon, 1986; Erez et al., 1979). With this as a premise, blueberry (Vaccinium section Cyanococcus) cultivars differing in their chilling requirement were used to study changes in bud proteins specifically associated with dehardening or dormancy. This was accomplished by subjecting cold-acclimated plants (where buds had met their respective $50 \%$ chilling requirement) to controlled-temperature regimes, warm enough to cause dehardening without negating chill unit accumulation, i.e., without affecting the dormancy status of the buds (Arora et al., 1997). All of the above three studies led to the conclusion that metabolism of certain dehydrins, a subgroup of late embryogenesis abundant (LEA) proteins, referred to as the D-11 family (Close, 1997), was more closely associated with cold-hardiness transitions rather than bud dormancy (reviewed in Rowland and Arora, 1997). Additionally, work with the sibling peach system indicated a potential association of certain bark-storage proteins with dormancy induction or release (Arora et al., 1992, 1996). Dehydrins, ubiquitous hydrophilic proteins, are believed to protect plant cells against cellular dehydration (such as freeze-induced desiccation) and therefore are expected to accumulate in cold-hardened tissues. However, Faust et al. (1997) speculated that dehydrin accumulation might also be involved in bud endodormancy. This hypothesis was based on the results from MRI studies that show low T2 values, hence an increase in bound vs. free water, in the buds during late fall or early winter (Faust et al., 1991), an observation later confirmed by $1 \mathrm{H}-\mathrm{NMR}$ analysis of water status in grape buds (Fennel and Line, 2001). Faust et al. (1997) proposed that dehydrins, apparently triggered by low temperatures and abscisic acid (ABA), bind water, which leads to freeze protection and simultaneous deepening of dormancy.

Manipulation of ENDOgenous ABA LEVELS AND ITS EFFECT ON ENDODORMANCY AND/OR COLD HARDINESS. ABA is a well-known waterstress-inducible plant hormone and a growth inhibitor. It has long been thought to mediate short-day-induced growth cessation and dormancy induction in buds; however, its role in that capacity has been questioned by many based on experimental evidence suggesting otherwise (Barros and Neill, 1989; Dumbroff et al., 1979; Iwasaki and Weaver,
1977; Lenton et al., 1972; among others). ABA metabolism has also been implicated in cold-acclimation physiology, whereby either short photoperiod, low temperature, managed water-stress, accumulation of $\mathrm{ABA}$, or exogenous application of $\mathrm{ABA}$ alone has been shown to enhance cold hardiness in certain herbaceous and woody species (Guy, 1990). The question now arises: How can one study ABA's involvement, if any, in dormancy or cold acclimation separately? Welling et al. (1997) and Rinne et al. (1998) recently conducted experiments either by manipulating endogenous ABA content of buds or by using an ABA-deficient mutant of birch (Betula pubescens) to address this question. Their results indicate that wild-type birch expressed elevated ABA levels before the onset of cold-acclimation under short day or natural field conditions. This was accompanied by tissue desiccation and accumulation of certain dehydrin proteins. By contrast, the mutant type had reduced water loss and reduced tolerance to low-temperature stress and absence of dehydrin accumulation under similar conditions. However, short-day conditions were still able to induce dormancy in ABA-deficient mutants (Rinne et al., 1998), which runs counter to the theory of ABA involvement in dormancy induction in birch. Welling et al. (1997) experimentally increased ABA content of long-day-exposed buds of the wild type birch by spraying ABA and by water stress. This treatment improved bud cold-hardiness without inducing growth cessation. Moreover, ABA elevation in birch buds did not occur under $95 \%$ relative humidity $(\mathrm{RH})$ or with fluridone (inhibitor of $\mathrm{ABA}$ synthesis) application even in the presence of short-day conditions. However, after $21 \mathrm{~d}$ at $95 \% \mathrm{RH}$ and short-day conditions, dormancy was still induced, whereas fluridone treatment significantly reduced bud cold hardiness. These results indicate that involvement of ABA is more direct in the photoperiodic control of cold acclimation in birch than in the induction of bud endodormancy.

\section{BUD DORMANCY INDUCTION}

Hormonal aspects. Since Hemberg (1949), hormones have been inextricably linked to woody bud dormancy induction and are implicated as a means by which plants respond to environmental cues. The term dormin was later proposed for substances that appeared to function as endogenous dormany inducers (Eagles and Wareing, 1963). The path to endodormancy induction is a continuum, which in some plants begins as early as budbreak in the spring. While it has been tempting to explain bud dormancy on the basis of hormonal regulation alone, dormancy is controlled by numerous integrated plant structures and functions (Crabbe, 1994; Simpson, 1990). Initial studies (e.g., Dennis and Edgerton, 1961; Nitsch, 1957; Phillips and Wareing, 1958; Samish, 1954; Wareing, 1956) were followed in the next 3 decades by a series of studies that monitored endogenous levels of hormones within whole buds, leaves, stems, cambium, and root tissues under natural fall and dormancy-inducing controlled-environment conditions. While relatively easy to apply and measure responses, many other problems are associated with traditional exogenous application of hormones in addition to degradation and differential responses between the widely available commercial ( \pm )-ABA and the natural (+)-ABA (Wilen et al., 1996). For example, long-distance signaling from root to leaf tissues in terms of $\mathrm{ABA}$ flux within the plant is regulated by $\mathrm{pH}$ changes and environmental stress. Freundl et al. (2000) showed root uptake of ABA is reduced by Casparian strip formation in the hypodermis. Under hydroponic or tissue-culture conditions, ABA may be lost to the medium if it is alkaline relative to the root cortex and, thus, root-zone $\mathrm{pH}$ and ABA concentration may modify root-to-shoot signaling as they affect apoplastic transport of ABA. Thus, a lack of response to exogenous ABA application may be a function of these effects. Sauter et al. (2001) also make additional important points including the significance of assessing ABA in specific cells. For example, authors of older literature quantified ABA in fully expanded leaf laminae rather than in the growing cells of leaf bases. Thus, the correlation between ABA accumulation in fully expanded cells and growth may not be relevant. An interesting study by Strauss et al. (2001) examined the subcellular distribution of ABA by using a single-chain ABA-binding antibody in Solanum tuberosum. They determined that leaves of young plants developed in the absence of ABA while leaves of older plants developed in the presence of ABA. Importantly, they demonstrated that exogenously applied ABA was 
distributed differentially from compartmentalized endogenous ABA within the cell. ABA-binding proteins might exist in the cytosol and/or endoplasmic reticulum and prevent $\mathrm{ABA}$ distribution based on cellular $\mathrm{pH}$ gradient alone. Therefore, localization of hormones such as ABA (and perhaps $\mathrm{GA}$ ) and examination of $\mathrm{pH}$ alterations during endodormancy induction in the apex are critical aspects to understanding the regulation of growth and dormancy.

Additional factors to consider include 1) the use of lateral vs. terminal buds; 2) distinguishing determinate and indeterminate growth; 3 ) differential photoperiodic response of young vs. mature leaves; 4) long-day photoperiod treatment just above the critical photoperiod (Eagles and Wareing, 1963; Hocking and Hillman, 1975); 5) use of whole buds vs. partitioned bud tissues; and 6) sampling of buds at quantitatively defined stages of dormancy (Fuchigami et al., 1982, Fuchigami and Wisniewski, 1997). Results are also complicated by the finding that hormone levels varied from basal to apical portions and changed from the fall through winter (Rinne et al., 1994 b; Saure, 1985) and the uncertainty of whether the observed changes were regulating factors or were simply a result of dormancy induction. Localization of hormones at the cellular level and assessing sensitivity vs. quantity of hormone are also important considerations. Knowledge of hormonal regulation of processes has become increasingly more complex, particularly with recent findings of auxin- and ethylene-triggered ABA induction revealing many more responses mediated by ABA than originally considered (Grossman and Hansen, 2001; Sharp et al., 2000). While many detailed studies have been performed, it is against rigorous criteria that the literature should be examined. Evidence for GA involvement in dormancy is addressed under the section Transgenic Approaches.

MOISTURE AND WATER ASPECTS. While angiosperms originated in humid tropical regions where temperature, daylength, and precipitation were stable throughout the year, one of the major evolutionary forces differentiating plant species was environmental change (Okubo, 2000). Some deciduous temperate-zone tree species probably expanded from these more tropical regions due to the cyclic wet/dry season and the subsequent adaptation of leaf abscission during the dry period. Frankie et al. (1974) found that $75 \%$ of the 113 tropical deciduous forest trees of Costa Rica lose their leaves during the dry season.

Water status of meristems of droughted plants is probably well buffered against drought stress (Sauter et al., 2001). They cite Thomas et al. (1988) where maintenance of turgor in intercalary meristems of grass under drought stress was demonstrated. Nevertheless, plant tissues can be extremely sensitive to minor alterations in water potential (Levitt, 1980). Much evidence supports a relationship between ABA concentration and bud water content under either short-day or water stress-induced dormancy in Betula pubescens (Rinne et al., 1994 a, 1994b; Welling et al., 1997) and Vitis vinifera 'Merlot Noir' (Koussa et al., 1998). Depth of dormancy has been proposed to be related to endogenous levels of ABA (Tamura et al., 1993) and the water status of the bud. As previously mentioned regarding Betula pubescens, short day induced a transient $\mathrm{ABA}$ elevation that did not occur under $95 \% \mathrm{RH}$ (Welling et al., 1997). However, after $21 \mathrm{~d}$ at $95 \%$ RH and short-day conditions, dormancy was still induced. Water content of buds decreased after $4 \mathrm{~d}$ of short-day exposure but remained stable throughout the $21 \mathrm{~d}$ sampling period in long-day plants. No difference in percentage water content was observed in leaves of either short-day- or long-day-treated leaves. The initial decline in the growth rate of field-grown Salix viminalis trees was not induced by photoperiod but was coincident with declining leaf-water potentials. In seeds of Arabidopsis thaliana limited access to water appeared to be the primary trigger for developmental arrest (Karssen et al., 1983).

Using magnetic resonance imaging, Faust et al. (1991) found endodormant buds had less free water than ecodormant buds, suggesting chilling-requirement satisfaction was associated with the conversion of water from the bound to free state. Bound-to-free water changes occurred during chilling-requirement satisfaction in the absence of any change in total water content (Parmentier et al., 1998). The researchers reported Vaccinium cultivars with the deepest dormancy and longest chilling requirement also had the most bound water. Bound water was subsequently shown to increase with endodormancy and freezing tolerance in peach buds (Erez et al., 1998), and either short photoperiods or low temperatures could induce this response. They concluded that bound water status was associated with low temperature stress tolerance rather than directly to dormancy itself. Gardea et al. (1994) developed an improved NMR method to distinguish different stages of dormancy in Vitis vinifera 'Pinot Noir' according to the state of water within the bud. Using 1H-NMR, Fennell et al. (1996) showed that changes in bud water state occurred after 2 weeks of short day photoperiod exposure in Vitis riparia. Fennell and Line (2001) determined that there was an increasing amount of bound water with endodormancy in both the grape buds and cortex/gap tissue adjacent to the bud.

Aquaporins are a relatively newly recognized class of membranebound water-channel proteins that can increase water transport across membranes 20-fold over diffusion alone (see Maurel, 1997 for a review). ABA, GA3, and desiccation induce these plasmamembrane intrinsic proteins (PIP) in Arabidopsis, while salt stress down-regulates PIP in Mesembryanthemum crystallinum. It is not known if dormancy induction may be, in part, regulated through dehydration stress via alterations in the quantity or activity of aquaporins. Localization of aquaporins and their functional physiology during dormancy induction (or release) in apical, bud-scale, and subapical meristematic regions will also be an important component of future research.

\section{BUD DORMANCY RELEASE}

It is beyond the scope of this review to summarize the numerous papers examining physiological phenomena affecting the timing of bud burst. Several other extensive reviews were suggested earlier. However, different approaches to examining mechanisms of dormancy release are emerging. One approach (outlined in the section Apical Meristem Dynamics) is based on regulation within the apical meristem itself by changes in the cell-to-cell communication and plasmodesmatal connections (Jian et al., 1997; Rinne et al., 2001; van der Schoot, 1996) or in the cell cycle (MacDonald, 2000; Rohde et al., 1997). Another approach centers around the regulation of water where initial reports based on supercooling examined the vascular connections into the bud (Ashworth, 1984; Quamme et al., 1995; Sakai, 1979). More recently, the sequence and regulation of water uptake into the bud (de Fay et al., 2000) and water status/availability (Faust et al., 1997) during dormancy has been addressed. Or et al. $(2000,2002)$ have taken the approach of studying molecular events involved in the perception and transduction of dormancy-breaking signals during chemical-induced dormancy release in a Vitis model (see below). The approach of Champagnat (1989) and others (for a review see Crabbe and Barnola, 1996; Faust et al., 1997) is based on a mechanism of dormancy induction (and release) via a metabolic or communication block, or a permeability barrier between the bud and adjacent tissues. Gevaudant et al. (2001) have studied both the buds and the underlying tissue in peach and found greater accumulation of PPA (Prunus persica $\mathrm{H}^{+}$-ATPase) transcripts in the underlying bud tissues compared to the buds themselves at the beginning of the dormancy period (October). This group attributed increased sucrose absorption in tissues underlying the bud during October to a stimulated $\mathrm{H}^{+} /$sucrose co-transport driven by PPA genes and suggested this to have a role in paradormancy. They also hypothesized that chilling-induced specific decrease in certain PPA isoforms in tissues underlying the buds in November and December could be involved in the evolution from paradormancy to endodormancy. Finally, while most work to date has focused on hormonal control of dormancy release, which, when, how, and to what degree hormones are involved is still uncertain, and evidence both supporting and refuting various growth regulators can be found in recent literature. What is clear is that, aside from more useful hormonal localization studies and use of mutants and transgenics, continued gross analysis of hormone presence or absence during dormancy release will not enable definitive mechanisms to be tested.

MOLECULAR MECHANISM OF CHEMICAL-INDUCED DORMANCY RELEASE. One of the challenges the horticultural industry has faced for many years is the economic production of temperate (or relatively high chilling requiring) fruit in warmer climates due to the lack of sufficient chilling hours required to overcome floral and vegetative bud dormancy. An example of the effect of lack of chilling in apple and peach grown in southern Mexico is illustrated in Fig. 1. For successful production of temperate fruit in these regions, it is necessary to break bud dormancy by using chemicals or other physical means. Alternatively, one could 

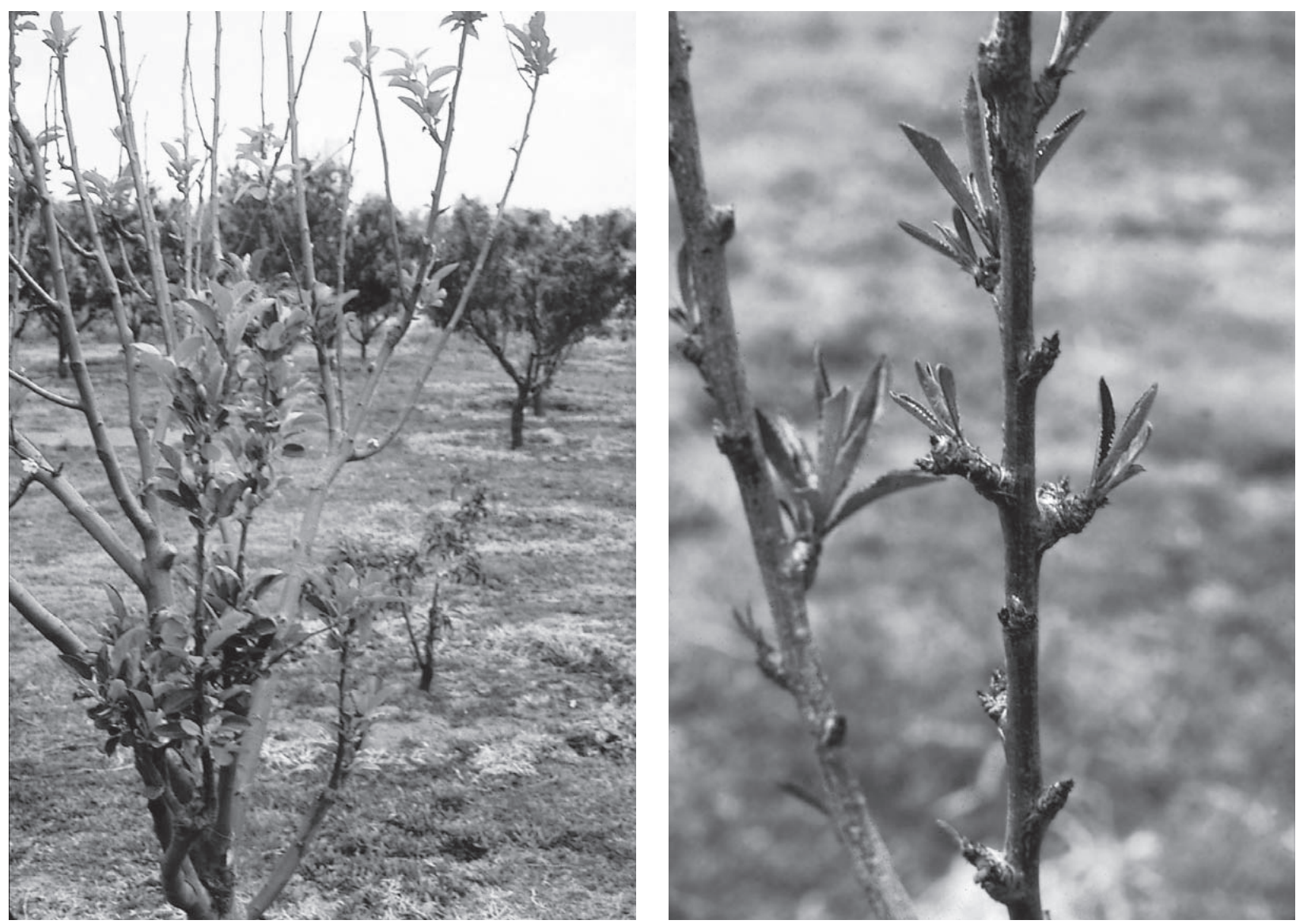

Fig. 1. Effect of lack of chilling on budbreak in apple and peach grown in Chapingo, Mexico. (left) Apple (Malus pumila 'Winter Banana') tree with barren branches as a result of insufficient chilling. Growth is primariliy from tips of shoots, with little or no growth of lateral buds. (right) Young peach (Prunus persica) tree with slow-growing shoots as a result of lack of chilling. Photo courtesy of Frank Dennis, Michigan State University.

breed new varieties that have a low chilling requirement. Since Denny and Stanton (1928), many reports have been published on regulating dormancy and budbreak (e.g., references in Erez et al., 1971; Iwahori et al., 2002; Saure, 1985) as well as the commercial use of dormancybreaking chemicals in the last few decades. However, one of the unresolved issues with the commercial application of these chemicals is when to apply the treatment because their efficacy and phytotoxity depend on the stage and depth of endodormancy (Erez, 1987; Erez et al., 1971; Fernandez-Escobar and Martin, 1987; Siller-Cepeda et al., 1992; Wood, 1993). So far, chill-unit accumulation has been typically used to estimate the depth and progress of bud dormancy largely due to the absence of visual bud changes during dormancy and/or due to lack of endogenous markers available for dormancy status.

Understanding the network of biochemical pathways (involving signaling molecules and target enzymes/genes) underlying dormancy release may help develop markers for proper timing of rest-breaking practices and for marker-assisted breeding (Tamura et al., 1998). Such knowledge may lead to the development of new dormancy-breaking strategies that are environmentally safe and nontoxic to plants and also understanding the mechanism of dormancy release by such approaches that have already been tried (Honjo et al., 2002; Rinne et al., 1997; Shirazi and Fuchigami, 1995; Tamura et al., 2002; Tanino et al., 1989 Wisniewski et al., 1997). Work on this theme was recently initiated by Or and co-workers with an objective to identify genes and gene products that may mediate the signal transduction of a dormancy release signal or derepression of meristematic activity. By achieving controlled dormancy release in grape buds with hydrogen cyanamide (HC) application and by comparing RNA populations from $\mathrm{HC}$-treated and control buds by differential display, they have identified transcripts for an sucrose non fermenting (SNF)-like protein kinase that is up-regulated during incipient dormancy-release (Or et al., 2000, 2002). Because SNF-like protein kinases have been implicated as stress receptors in animal and yeast systems and some of the plant SNF-like protein kinases are transcriptionally regulated by stress stimuli
(Anderberg and Walker-Simmons, 1992; Hardie, 1994), Or et al. suggest that this kinase might be involved in perception of stress signal induced by $\mathrm{HC}$ in grape buds. They theorize the biochemical identity of the signal to be a transient disruption of respiratory metabolism caused by $\mathrm{H}_{2} \mathrm{O}_{2}$, presumably generated by $\mathrm{HC}$-induced oxidative stress, an explanation supported by their observations on the complete shut off of catalase (free radical scavenger) gene expression soon after HC application. This theory is in line with the well-known effect of several dormancy-release chemical treatments (e.g., azide, cyanide, mineral oils, thidiazuron) on respiratory metabolism (Faust and Wang, 1993; Wang et al., 1991) and on reduced catalase activity in response to thiourea and cyanamide treatments (Nir et al., 1986). However, a series of reports by Wang et al. (reviewed in Rowland and Arora, 1997) during the 1980s and 1990s showed increased activities of peroxide scavenging system enzymes with apple budbreak, induced by chemicals or cold or heat treatment. Electron spin resonance spectroscopy showed TDZ treatment diminished free radical formation and induced budbreak in dormant apple buds (Wang and Faust, 1988). These observations indicate that dormancy release in buds coincides with upregulation of antioxidant system. It is noteworthy that cold acclimation of woody perennials, a low-temperature, chill-induced response, is known to be often accompanied by an upregulation of antioxidant machinery, required, presumably, for protection against freezing stress (Guy, 1990). Conceivably, the biochemical events resulting from HCN treatments may constitute a stress response to a shock treatment and differ from those elicited by natural cumulative chilling. Comparative gene-expression studies during dormancy release after artificial (chemicals) and natural (chilling and sublethal freezing) treatments would be key to unraveling this question and advancing the mechanistic understanding of bud dormancy release. As stated earlier, the efficacy of chemical treatment in dormancy release depends on the stage and depth of endodormancy. Therefore, any proposed cellular mechanism for chemical-induced dormancy release must be examined within this context.

Bud DoRmancy Release MOdels Under a CHanging Climate. Bud 
dormancy release models have evolved from one based on the linear accumulation of chilling hours below a $7^{\circ} \mathrm{C}$ critical temperature (Weinberger, 1950) to a dynamic model based on a chilling unit response curve (Seeley, 1996), which takes into consideration the nonlinear response to chilling temperatures over time. However, limitations include the effect of high temperature negation of chilling unit accumulation (Erez and Lavee, 1971; Seeley, 1996) as well as identifying the point when chilling units begin to accumulate (Seeley, 1996). Saure (1985) earlier proposed a dual model of temperature action in dormancy release in which there was separate regulation by temperature on dormancy promotion and release. Models should also take into account dormancy stage-dependent bud sensitivity to temperature (Fuchigami et al., 1982), photoperiod and temperature interaction (Hanninen, 1995), as well as the effect of diurnal day and night temperature differences. Sugiura et al. (2002) proposed a developmental rate (DVR) model, which characterizes the relationship between endodormancy developmental rate and temperatures ranging from -6 to $+24^{\circ} \mathrm{C}$. Temperature effects on chilling requirement satisfaction have been of particular concern with evidence of changing global climates.

Based on more than 30 years of data at the International Phenological Gardens throughout Europe, the mean annual growing season was extended by $10.8 \mathrm{~d}$ and was attributed to a mean temperature increase (Menzel and Fabian, 1999). Fluctuating midwinter temperatures are also of concern. Low midwinter temperatures are the main limiting factors to apple production in the Okanagan Valley of British Columbia (Caprio and Quamme, 1999) and Finland (Linden, 2001). Fulfillment of the chilling requirement and potential premature budbreak resulting in midwinter or spring injury have been an active topic of research for a number of years (Cannell and Smith, 1983). However, Hanninen (1995) indicates that the risk of premature bud burst with associated frost injury due to climatic warming is overestimated by most models. He suggests three steps to obtain realistic ecophysiologic models for bud burst phenology in trees: 1) identifying physiological phenomena affecting the timing of bud burst; 2) summarizing all the models on environmental regulation of physiologic phenomena; and 3) testing the hypothetical models with the species and provenances of interest. Ultimately, bud dormancy release models will only be as accurate as our understanding of the underlying cellular mechanisms regulating endodormancy release.

\section{APICAL MERISTEM DYNAMICS DURING DORMANCY CYCLING: CELL-TO-CELL COMMUNICATION AND CELL-CYCLE SIGNALLING}

Dormancy is regarded as the temporary suspension of morphogenetic activity. Because the transition from dormancy to proliferation occurs in the growing points, dormancy is integral to the apical meristem. A developmentally active apical meristem (dormancy release), however, could result from the restoration of cell-to-cell signaling networks among individual cells of the apical meristem that had been disrupted or discontinued during the dormancy induction. Resumption of cellto-cell communication, regulated by plasmodesmata (PD), may allow for symplastic movement of small signaling molecules, hormones, or proteins responsible for dormancy release. This line of thinking has led some researchers in recent years to investigate the role of PD connection (or lack thereof) in the shoot apex in dormancy regulation of some woody plants. Efforts have also been made to identify the physiological or molecular mechanisms that may underlie the blockage or formation of symplasmic connections during dormancy induction or release (naturally or under controlled environments) of certain woody plants.

Jian et al (1997) reported that during short day exposure and the development of dormancy in poplar (Populus deltoids), frequency of PD in cell walls between neighboring cells in apical buds decreased and the diameter of pores was reduced. They speculated that an expected disruption of intercellular communication arising from these perturbations, in turn, may have led to events associated with growth cessation. In addition, active alterations in the subcellular localization of $\mathrm{Ca}^{2+}$ in the meristem during dormancy induction were observed, in that relatively large amounts of $\mathrm{Ca}^{2+}$ precipitates were found in cytosol at dormancy induction compared to that at the nondormant state. Could the elevated levels of cytosolic $\mathrm{Ca}^{2+}$ regulate PD permeability and thereby affect cell-to-cell communication? Are shifts in cytosolic $\mathrm{Ca}^{2+}$ levels triggered by symplasmic blockage in the first place? Or, are cytosolic $\mathrm{Ca}^{2+}$ alterations reversed at dormancy release? These questions were not investigated in the above study. However, a study using an artificial increase in $\mathrm{Ca}^{2+}$ in Chara cells of spring branch internode (by $\mathrm{Ca}^{2+}$ ionophore A23187) found that it significantly restricted intercellular communication in ways similar to those found in vegetatively dormant cells in winter branch internodes (Shepherd and Goodwin, 1992).

A recent report by Rinne et al. (2001) found that in birch, symplasmic pathways (plasmodesmatal connections) are shut down in the apical meristem during dormancy induction in response to short day. Blockage of symplasmic connections was brought about by the formation of 1,3- $\beta$-D-glucan, presumably produced by local activation of 1,3- $\beta$-D-glucan synthase complex (Rinne and van der Schoot, 1998), which is believed to prevent the functioning of the apical meristem as an integrated whole. In the proposed model, chilling is believed to restore the symplasmic organization of birch apical meristem by enhancing the production of $1,3-\beta$-D-glucanases and their delivery into the vicinity of plasmodesmata where glucans are digested by glucanases. This, in turn, results in restoration of symplasmic connections, thereby allowing cells in the apical meristem to exchange cell metabolites and acquire growing capacity (Rinne et al., 2001). These researchers also hinted at a probable activation of glucanases during dormancy release induced by GA that may have been synthesized in individual cells within the apical meristem in response to chilling. This explanation, though needing experimental evidence, is in line with earlier observations that, whereas chilling promotes release from dormancy, application of exogenous GA to the bud itself (not to other plant parts) can substitute for it (Lang, 1957; Purvis, 1961), and that GA4 activates the transcription of 1,3- $\beta$-D-glucanase genes in tobacco seeds, thereby promoting germination (Leubner-Metzger et al., 1996). How chilling signal perceived and translated into causing the stimulation of GA biosynthesis is not known at present. The model proposed by Rinne et al. (2001) for dormancy cycling in birch provides a useful framework for the study of other plant systems that display dormancyproliferation cycles. A good model would, ultimately, have to explain the apical meristem dynamics vis-à-vis dormancy release in low-chilling vs. high-chilling requiring species.

A detailed study by Owens and Molder (1973) in douglas fir indicated mitotic activity and dormancy were related to carbohydrate levels within the bud and subtending shoot. Lack of sufficient carbohydrates may lead to the accumulation of cells in the G1 stage. Distinct zones were characterized in terms of mitotic frequency and level of DNA within the vegetative apex in douglas fir. The relative amount of DNA per nucleus within the apical initials was markedly lower at dormancy onset compared to active growth with no cell divisions apparent in either central mother cells or the protoderm. In mammalian cells, cell-cycle signaling is thought to occur through a structurally unique family of protein serine-threonine kinases, ATM (ataxia-telangiectasia mutated) and ATR (ATM and Rad 3-related) kinases, in response to various environmental stress agents through cell cycle checkpoints (Abraham, 2001) and could potentially represent controlling points of plant growth and development.

Recently, Rohde et al. (1997) transformed poplar with cell-cycle genes and determined short-day treatment triggered the most marked change in the cell cycle. Both photoperiod and temperature had opposite effects on the expression of cell-cycle promoters and suggested differential regulation of the cell cycle where photoperiod may accumulate more cells in G1 and temperature accumulates more cells in the $\mathrm{G} 2$ stage.

Dormancy itself is the end product of a long sequence of events, which in the case of conifers originates with budbreak in the spring. Macdonald and Owens (1993) demonstrated strong genetic control of bud-scale initiation within the apical meristem in response to shortday treatment in douglas fir. The process of early to late bud scale initiation followed by early to late leaf initiation culminated in bud dormancy induction in these coniferous species. Baldwin et al. (2000) induced bud scale maturation on in vitro-grown Amelanchier alnifolia with $50 \mu \mathrm{M} \mathrm{ABA}$ and $5.5 \mu \mathrm{M} \mathrm{BA}$. However, ABA alone only halted growth but did not produce mature bud scales. The absence of the synthetic auxin, NAA, was a requirement for bud-scale maturation in 
this system. While it is clear that the transition from leaf to bud scale or cataphyll development within the apical meristem is one of the first morphologic shifts in buds of woody plants, the molecular switch and signal transduction cascade inducing this response is not clear. Shoot apical meristem mutants of model systems such as Arabidopsis (Laufs et al., 1998) may be used to test specific hypotheses.

\section{GENETIC CONTROL OF ENDODORMANCY-RELATED TRAITS IN WOODY PERENNIALS}

For the 40 to 50 years leading up to the 1990 s, little effort was made to understand control of endodormancy from a genetic point of view because most endodormancy-related traits were considered multigenic and, therefore, too complex. Indeed, the few dormancy reviews that summarized genetic analyses before 1990 (Dennis, 1987; Saure, 1985) included very little that directly related to the genetics of bud endodormancy except for a discussion of a nondormant mutant phenotype in hazelnut (Corylus avellana) (Thompson et al., 1985), a discussion of the heritability of low-chilling requirement, and a summary of chilling requirements for some deciduous fruit tree species. The development of new tools for dissecting quantitative traits into their Mendelian components (Tanksley and Hewitt, 1988; Tanksley et al., 1989) in the last 15 years has opened the door for the genetic studies on endodormancy-related traits that have followed.

EARLY STUDIES. There are many obstacles to conducting genetic research in woody perennials, including long generation times, high ploidy levels, self- and cross-incompatibility, and inbreeding depression (Janick and Moore, 1975; Moore and Janick, 1983). Before 1995, few genetic studies of endodormancy-related traits (traits associated with induction, maintenance, or release from endodormancy) in woody perennials had been attempted. Those studies that had been carried out included estimates of heritability and classic Mendelian genetic analyses of a few traits. Genetic studies of hazelnut (Thompson et al., 1985) and peach (Rodriguez et al., 1994) mutants with apices that never go dormant suggested that this nondormant phenotype is controlled by a single recessive gene. Heritability estimates for fall leaf abscission and spring bloom date in peach indicated that these traits have strong genetic components (Hansche, 1990). Likewise, broad-sense heritability estimates for the duration of bud dormancy in apple (Malus $\times$ domestica Borkh.) indicated that chilling requirement has a strong genetic component (Hauagge and Cummins, 1991). Genetic studies of progeny from open and control cross-pollinations of the low-chilling apple cultivar Anna provided evidence that low chilling requirement in this cultivar is controlled by at least one major dominant gene, and that minor genes modulate its effects (Hauagge and Cummins, 1991). Oppenheimer and Slor (1968) also observed dominance of the very low chilling character in other crosses of apple. The results from hazelnut, peach, and apple are not contradictory if one hypothesizes that the recessive nondormant mutations in hazelnut and peach affect gene(s) critical to the induction of endodormancy, and that the dominant lowchilling alleles of apple are of different genes affecting the maintenance or duration of endodormancy (Rowland and Arora, 1997).

QTL ANALYSES OF BUD SET AND BUD FLUSH. With the exception of the nondormant trait described above, most endodormancy-related traits are inherited in a quantitative fashion, displaying continuous distributions in progeny tests (Billington and Pelham, 1991; Bradshaw and Stettler, 1995; Farmer and Reinholt, 1986; Howe et al., 1999, 2000; Lawson et al., 1995). This is indicative of multigenic control. Detection of endodormancy-related quantitative trait loci or QTLs, by their cosegregation with molecular markers, was first reported in woody perennials in 1995 from research groups working on apple (Lawson et al., 1995) and poplar (Populus spp.) (Bradshaw and Stettler, 1995). In apple, a small F1 population (double pseudotestcross format), derived from a cross of 'Rome Beauty' and the ornamental crabapple 'White Angel', was used in an attempt to detect genes with large effects on several developmental traits including timing of vegetative and reproductive bud flush (Lawson et al., 1995). Timing of bud flush is important because, if bud flush occurs too early in the spring, growing tissues may be damaged by a late frost. On the other hand, if bud flush occurs too late in the spring, the growing season may be significantly shortened, which is an important consideration in the forestry industry.
Alternatively, the timing of fruit development may be affected, which is an important consideration in the fruit crop industry. In this apple population, timing of vegetative bud flush was found to be associated with two molecular markers and one morphological branching marker, $\mathrm{Tb}$ for terminal bearing, all on linkage group 6 . Thus, it was suggested that the timing of vegetative bud flush may be a pleiotropic effect of Tb. The timing of reproductive bud flush was associated with the isozyme marker Prx-c, localized to linkage group 5. Results suggested that a dominant allele at a locus designated $R b b$ promoted early initiation of reproductive budbreak. In poplar, a small F2 population (referred to as family 331) derived from a cross between interspecific F1 hybrids [black cottonwood (Populus trichocarpa) clone 93-968 from Washington $\mathrm{X}$ eastern cottonwood (P. deltoides) clone ILL-129 from Illinois] was used for QTL analysis of vegetative bud flush (Bradshaw and Stettler, 1995). QTL analysis identified five QTLs, scattered among five different linkage groups, with major effects on the timing of vegetative bud flush. Three of the QTLs showed a dominant mode of action (early flush dominant to late flush), while the other two had an additive effect. Combining all five QTLs in a single model explained $85 \%$ of the genetic variance. In addition, broad-sense heritability was high, $98 \%$, for vegetative bud flush, indicating that environmental variation for this trait is extremely low.

After initial attempts to map timing of bud flush came the development of larger populations and better efforts to map these and other endodormancy-related traits. Using a larger F1 population of 172 apple trees from a cross between the columnar, or reduced branching mutant 'Wijcik McIntosh' and a standard form disease-resistant selection 'NY 75441-58', eight putative QTLs on six linkage groups were detected for vegetative bud flush (Conner et al., 1998). Combining all eight QTLs into a multilocus model explained $42 \%$ of the phenotypic variation. None of these eight QTLs, however, was localized to the linkage group having homology to the Tb-containing linkage group associated with vegetative bud flush in the 'Rome Beauty' $\mathrm{x}$ 'White Angel' population. In poplar, a large F2 population consisting of 346 progeny (referred to as family 822), was developed by crossing two F1s that were hybrids of the same black cottonwood clone '93-968' from Washington, used in development of the first smaller population, and another eastern cottonwood clone S7C4 from Texas (Frewen et al., 2000). The population was used for QTL analysis of fall bud set and spring bud flush and for mapping candidate genes with plausible roles in affecting these traits to test for colocalization with identified QTL. Timing of bud set is important because, if woody perennials do not set buds early enough and develop an adequate level of freezing tolerance, plants may be damaged by an early frost. On the other hand, setting buds too early shortens the growing season. Three QTLs associated with bud set and six QTLs associated with bud flush were detected. The three bud set QTLs were distributed over three linkage groups and the six bud flush QTLs were scattered over six linkage groups. The three bud set QTLs were identified on linkage groups that also contained bud flush QTLs. Thus, it was suggested that single QTLs could have pleiotropic effects on both traits as a result of shared components of a biochemical pathway. When a comparison was made of the bud flush QTLs identified in the 822 family to those in the 331 family, it was found that, of the five linkage groups containing bud flush QTLs in the 331 family, three of them had known homologs in the 822 family and all three contained bud flush QTLs. Two QTLs found in the 822 family, however, were not detected in the smaller 331 family. Five candidate genes putatively involved in the regulation of endodormancy were also mapped. These included phytochrome genes involved in the perception of photoperiod, $P H Y B 1$ and $P H Y B 2$, and genes involved in the transduction of abscisic acid response signals, $A B I 1 B, A B I 1 D$, and $A B I 3$. $P H Y B 2$, and $A B I 1 B$ were found to map near QTLs affecting both bud set and bud flush.

Most recently, bud flush QTLs were examined in douglas fir (Pseudotsuga menziesii Franco var. menziesii) over multiple years at multiple sites (Jermstad et al., 2001). Using an intraspecific F2 population (190 clones at a Washington site and 78 clones replicated at a site in Oregon), 33 QTLs affecting the timing of spring bud flush were identified. This is the total number of unique QTLs detected for two bud flush traits (lateral and terminal bud flush) at the two locations over multiple years (1995, 1996, 1997, and 1998 at the Washington site and 1995, 1996, 
and 1998 at the Oregon site) and estimated using two different models. If the number of QTLs associated with bud flush were counted in just one year at one site by using only one model, the highest number of QTLs per trait (for lateral or terminal bud flush) would be four, closer to the number detected in poplar. The 33 QTLs were distributed over 12 linkage groups and, in general, each explained a small percentage of the total phenotypic variation and were additive in effect. At the Washington site, but not at the Oregon site, several QTLs associated with the same trait were detected at the same map positions over multiple years. This may be due to the larger population size at the Washington site than at the Oregon site. Very few QTLs, however, were detected at both test sites suggesting that the QTLs associated with bud flush are expressed differently in different environments.

STATUS OF QTL aNd GENERATION MEANS ANALYSES OF CHILLING REQUIREMENT. Besides the bud set and bud flush QTLs that have been identified thus far, there are efforts underway to identify QTLs and modes of gene action associated with chilling requirement in blueberry (Vaccinium section Cyanococcus) (Rowland et al., 1999). There are several reasons for studying chilling requirement in blueberry species. Chilling requirement prevents growth during transitory periods of warm temperatures throughout a large portion of the winter and therefore helps synchronize plant growth with exposure to favorable environmental conditions. Together, chilling requirement and freezing tolerance determine to what degree temperate-zone fruit crops, like blueberry will survive the winter and early spring without shoot and flower bud damage. There has been and continues to be much effort focused on developing low-chilling blueberry cultivars for the southern United States through traditional breeding approaches (Hancock and Draper, 1989; Hancock et al., 1995). If markers linked to genes controlling chilling requirement were identified, they could be used in marker-assisted selection to streamline the breeding process. In addition, blueberry is a small-statured fruit crop amenable to experimentation in controlled environments, making it more suitable than most tree species for chilling-requirement studies.

Diploid testcross populations of blueberry (each comprised of $\approx 200$ plants), useful for detecting QTLs associated with chilling requirement, were developed by crossing $V$. darrowi diploid V. corymbosum hybrids ['Fla4B' ' 'W85-20' (\#5, \#6, and \#10)] back to another V. darrowi and another V. corymbosum selection, 'NJ88-13-15' and 'W85-23', respectively (Rowland et al., 1999). Testcross populations were developed because diploid blueberry tolerates little inbreeding; therefore, true F2 or backcrosses cannot be easily generated for mapping. Diploid $V$. darrowi is a southern evergreen, lowbush species whose habitat ranges from Florida to Louisiana. Vaccinium darrowi has been used extensively in blueberry breeding programs to introduce low chilling requirement into the typically high-chilling highbush background $(\mathrm{Gal}-$ letta and Ballington, 1996; Hancock and Draper, 1989; Hancock et al., 1995). The original $V$. darrowi parent plant used in developing these mapping populations, Fla4B, is, in fact, the original primary clone used in blueberry breeding programs to develop low-chilling southern highbush cultivars. 'Fla4B' was collected from Ocala, Fla., and has a low chilling requirement (Rowland et al., 1995, 1999). Vaccinium corymbosum is a wideranging deciduous, highbush species and includes diploids and tetraploids. Tetraploid V. corymbosum and V. corymbosum hybrid cultivars are responsible for most of the total annual production of commercial blueberries in North America (Ballington, 2001). The diploid V. corymbosum clone 'W85-20', the other original parent plant of these mapping populations, was collected from New Jersey. It has a much higher chilling requirement than 'Fla4B' (Rowland et al., 1995, 1999). Current genetic linkage maps of the V. darrowi and V.corymbosum testcross populations are comprised of $\approx 75$ and 85 molecular markers, respectively (L.J. Rowland, unpublished). Molecular markers include mostly randomly amplified polymorphic DNA(RAPD) markers as well as a few newly developed expressed sequence tag-polymerase chain reaction (EST-PCR) markers (Rowland et al., 2003).

Chilling requirement data collected from the testcross populations was used first in a generation means analysis (Beaver and Mosjidis, 1988; Mather and Jinks, 1982) to evaluate different additive and epistatic models that may explain chilling requirement gene action (Rowland et al., 1999). In this type of analysis, joint scaling tests (Mather and Jinks, 1982) are used to investigate gene action. The tests use parental, F1, and testcross population means (for chilling requirement) to estimate values for genetic components (additive and dominance components) and nonallelic (epistatic) interactions of a cross. The estimates are then used to fit genetic models to the data that best explain differences among means for the various populations. Unfortunately, the generation means analysis of the chilling requirement data failed to identify a genetic model that accurately predicted the chilling requirement means for the populations analyzed. An assumption of the generation means analysis is that the parents are homozygous for the trait of interest. Thus, this failure to identify a model suggested that one or both parents were heterozygous for genes having a major effect on chilling requirement. In support of this idea, chilling requirement values calculated for nine 'Fla4B' $x$ 'W85-20' F1 plants indicated that chilling requirement was segregating 1:1 in the $\mathrm{F} 1$ population, resulting in a lower-chilling class [four plants with chilling-requirement values in the range of 530 to 600 chill units $(\mathrm{CU})$ ] and a higher-chilling class of F1s (five plants with chilling-requirement values from 800 to $1010 \mathrm{CU}$ ). In addition, chilling-requirement values calculated for offspring resulting from crosses between 'Fla4B' and other $V$. darrowi plants and 'W85-20' and other $V$. corymbosum plants suggested that the $V$. darrowi parent population was the one that was heterozygous for chilling-requirement genes. From the generation means analysis, the chilling-requirement means of the $V$. darrowi and $V$. corymbosum testcross populations were skewed more towards the $V$. darrowi parental and $\mathrm{F} 1$ populations, respectively, suggesting that low chilling requirement is a dominant trait. On the other hand, the mean for the F1 population, because it was segregating for chilling requirement, was about halfway between the means for the two parental populations, suggesting a low degree of dominance or an additive trait. The result, therefore, of the generation means analysis was a lack of fit of any models tested.

Although the blueberry populations did not conform to the assumptions of a generation-means analysis, important information was learned from the attempted analysis that could be used in a simple Mendelian genetic analysis of inheritance. First, the means of the testcross populations suggested that low chilling requirement is a dominant or partially dominant trait, which is consistent with the findings from apple (Hauagge and Cummins, 1991). Second, the original $V$. darrowi parent Fla4B is apparently heterozygous for a major lowchilling-requirement gene (putative genotype $A a$ ), while the testcross $V$. darrowi parent 'NJ88-13-15' is probably homozygous $(A A)$. Third, the V. corymbosum parents, original 'W85-20' and testcross 'W85-23', are probably homozygous recessive for this low-chilling-requirement gene $(a a)$. And, fourth, the F1 population is segregating for low chilling requirement ( $A a$ and $a a$ types), making only testcrosses involving the low-chilling F1s (\#5 and \#10; $A a$ ) and 'W85-23' ( $a a$ ) useful for mapping purposes. This genetic model, which assumes one major dominant gene for low chilling requirement (and other minor genes with various effects on chilling requirement) and the genotypes described above for the original parents, F1s, and testcross parents, fairly accurately predicts the segregation ratios observed in the various subpopulations of the testcrosses (L.J. Rowland, unpublished).

Recent attempts were made to map QTLs for chilling requirement by using the molecular marker and chilling requirement data that are available for the entire $V$. corymbosum testcross and then, again, using only the data from the two subpopulations involving F1s \#5 and \#10 (L.J. Rowland, unpublished). Both attempts failed to identify any QTLs with log-likelihood scores $>2.0$. The current genetic linkage map for the V.corymbosum testcross is probably not saturated enough to detect QTLs. Thus, efforts are underway to add more molecular markers to the map, especially the newly developed EST-PCR markers (Rowland et al., 2003).

A MOLECUlar MARKER FOR LOW-TEMPERATURE INDUCTION OF VEGETATIVE MATURITY. Photoperiod is widely considered to play the major role in inducing dormancy (Bigras and D'Aoust, 1993; van Huystee et al., 1967). However, it is also known that low temperature alone can induce dormancy in northern provenances of some woody species (Howell and Weiser, 1970; Junttila, 1980; Stevenson, 1994; Tung and Deyoe, 1991). Dormancy induction may also be stimulated with low temperature in southern provenances but only in conjunction with short days (Heide, 1974; Junttila, 1980, 1982; Stevenson, 1994). Howe et al. (2000) concluded that low temperature deserves greater attention in 
dormancy induction research. Global climate-change scenarios predict mean annual temperatures to rise and be accompanied by increasingly unpredictable weather patterns during seasonal transitions. Under this weather pattern, plants that can acclimate rapidly to more than one environmental cue will be able to maximize growth while minimizing exposure to potentially damaging conditions. Vegetative maturity (VM) is a critical point in the dormancy cycle before which plants are unable to cold acclimate significantly (Fuchigami et al., 1982).

Svendsen (2003) reported a sequence characterized amplified region (SCAR) marker that correctly (92\%) distinguished between low-temperature-induced (LTI) VM and short-photoperiod-induced VM. An F2 red-osier dogwood (Cornus sericea) population (191 seedlings), derived from a polycross of the F1 reciprocal-cross progeny of North West Territories (northern, early) and Utah (southern, late) ecotypes, was used as a model system and characterized for timing of VM induction. This trait had a continuous distribution, indicating complex genetic control (Eriksson et al., 1978; Hummel, 1982; Rehfeldt, 1977). After screening 515 RAPD primers, only one produced a polymorphism that differentiated between the LTI and photoperiod-induced VM subpopulations. This $\mathrm{F} 2$ population was further characterized for timing of spring budbreak. Regression analysis of the timing of budbreak against the timing of VM acquisition revealed a poor fit, suggesting these traits are under separate genetic controls that likely segregate independently. By contrast, the same regression analysis of the geographic ecotypes showed a strong correlation between early VM and early budbreak, consistent with plant adaptation and survival.

\section{TRANSGENIC APPROACH TO UNDERSTANDING REGULATION OF BUD-DORMANCY}

It is generally believed that initiation of cold acclimation during a seasonal cycle of a woody plant must be preceded by or coincident with growth cessation, i.e., formation of terminal buds (Fuchigami et al., 1971). Growth cessation (and endodormancy) is under photoperiodic regulation whereby short-day-induced cessation of apical growth in tree species is believed to be related to short-day-induced block(s) in gibberellin biosynthesis (Juntilla, 1990). Because phytochromes are the photoreceptors believed to play a role in photoperiod-sensing, they are good candidate genes for endodormancy-related traits. At least five phytochrome genes (PHYA-PHYE) exist and these genes have both overlapping and distinct functions (Whitelam and Devlin, 1997). Their role at the molecular level in photoperiodic perception in woody plants has recently been investigated with the help of transgenic technology. Using PHYA (phytochromeA) mutants of hybrid aspen (Populus tremula $\mathrm{X}$ tremuloides), Olsen et al. (1997) showed that over-expression of the oat $P H Y A$ prevented growth cessation, leaf abscission, and cold acclimation in Populus exposed to inductive conditions of short photoperiods and low temperatures. Another study showed reduced expression of PHYA accelerated bud formation in response to short days in aspen (Eriksson, 2000). Although no changes in the GA levels were detected in wild type and transgenic lines (Olsen et al., 1997), short-day-induced down-regulation of biosynthesis of the active gibberellin A1 was shown to be inhibited in the plants that over-expressed PHYA. Furthermore, the decline in IAA levels in the wild-type plants observed under short days was not evident in the mutants. Recent experiments with the PHYA overexpressing poplar mutant system achieved an induced bud set (but not winter dormancy) and increased cold hardiness by lowering GA content under changing day/night temperatures (J.E. Olsen, personal communication). This study also showed that the capacity for metabolic flow through GA19 was limited under short days compared to long days. The results summarized above demonstrate the importance of PHYA in the photoperiodic regulation of growth cessation that may be mediated via modified GA and auxin biosynthesis.

Unlike many woody perennials that are recalcitrant to transformation, poplars can be easily transformed using either Agrobacterium-mediated transformation or biolistics (Charest et al., 1997; Fillatti et al., 1987). The ability to transform poplar will undoubtedly result in the development of many more useful mutants in the near future through over-expression or knocking out expression of other candidate genes. This should help immensely to elucidate the role of these genes in the control of various endodormancy-related traits. This feature, together with the availability of genetic linkage maps, small genome size, etc., makes poplars ideal for molecular genetic studies of woody perennials (Howe et al., 1999). In fact, the PHYB gene has recently been mapped to a linkage group that contains both bud set and budbreak QTL (Frewen et al., 2000).

\section{THE FUTURE}

The field of plant molecular biology is advancing rapidly. This has made it possible for horticultural scientists to study gene expression and its regulation at a level that was not feasible just a decade ago. The advent of the functional genomics era has ushered in an optimism among scientists that understanding of the holistic biology of many growth and developmental processes will soon be realized. Significant progress has already been made on this front with model plant systems. Genomics technology could be used to also answer some basic questions about bud dormancy regulation in woody plants. For example, microarray technology could be used in carefully designed studies to identify genes that are differentially expressed during dormancy induction or release. This information could then be deciphered to differentiate sensing and signaling genes (e.g., kinases) from those that may be regulatory (transcription activators) or target genes for physiological response. Gene-mapping studies should provide information as to whether some of these genes map to linkage groups that control bud dormancy-related traits, as has already been achieved for at least some candidate dormancy genes in poplar. This could provide stronger evidence in favor of the gene dormancy cause-and-effect relationship. This information will also be of tremendous practical value in breeding programs by providing genetic markers for dormancy related traits. A logical next step to the QTL analyses that have already been performed in some plants is the use of molecular markers, linked to QTL with large effects on endodormancy-related traits, in marker-assisted selection. Another possibility is the use of these molecular markers to isolate the genes of interest by using BAC libraries and chromosome walking strategies. Comprehensive understanding of the molecular/biochemical network responsible for dormancy induction and release within an intact apical meristem and subtending tissues will allow for targeted manipulation of bud dormancy (breaking or delaying it using chemical or physical means) in horticultural crops for economic gains. Availability of new technologies has allowed dormancy researchers to bring this field from its humble beginnings to the cutting edge in the 21 st century, truly a science that has come of age. Fundamental understanding of the mechanism of dormancy induction and release, however, can ultimately only be achieved through a multidisciplinary approach involving horticulturists, physiologists, biochemists, and molecular geneticists at field, whole-organism, cell, and molecular levels.

\section{Literature Cited}

Abraham, R.T. 2001. Cell cycle checkpoint signaling through the ATM and ATR kinases. Genes and Dev. 15:2177-2196.

Anderberg, R.J. and M.K. Walker-Simmons. 1992. Isolation of a wheat cDNA clone for an abscisic acid-inducible transcript with homology to protein kinases. Proc. Natl. Acad. Sci. USA 89:10183-10187.

Arora, R. and M.E. Wisniewski. 1994. Cold acclimation in genetically related (sibling) deciduous and evergreen peach, Prunus persica. II. A60-kilodalton bark protein in cold acclimated tissues of peach is heat-stable and related to the dehydrin family of proteins, Plant Physiol. 105:95-101.

Arora, R., L.J. Rowland, and G.R. Panta. 1997. Chill-responsive dehydrins in blueberry: Are they associated with cold hardiness or dormancy transitions? Physiol. Plant. 101:8-16.

Arora, R., M.E. Wisniewski, and L.J. Rowland. 1996. Cold acclimation and alterations in dehydrin-like and bark storage proteins in the leaves of sibling deciduous and evergreen peach. J. Amer. Soc. Hort. Sci. 121:915-919.

Arora, R., M.E. Wisniewski, and R. Scorza. 1992. Cold acclimation in genetically related (sibling) deciduous and evergreen peach, Prunus persica. I. Seasonal changes in cold hardiness and polypeptides of bark and xylem tissues. Plant Physiol. 99:1562-1568.

Artlip, T.S., A.M. Callahan, C.L. Bassett, and M.E. Wisniewski. 1997. Seasonal expression of dehydrin gene in sibling deciduous and evergreen peach, Prunus persica. Plant Mol. Biol. 33:61-70.

Ashworth, E.N. 1984. Xylem development in Prunus flower buds and relation- 
ships to deep supercooling. Plant Physiol. 74:862-865.

Baldwin, B.D., M.S. Bandara and K.K. Tanino. 2000. Bud scale maturation in saskatoon berry (Amelanchier alnifolia) plantlets following in vitro hormonal treatments. Acta Hort. 520:203-208.

Ballington, J.R. 2001. Collection, utilization, and preservation of genetic resources in Vaccinium. HortScience 36:213-220.

Barros, R.S. and S.J. Neill. 1989. The status of abscisic acid in willow as related to the induction of bud dormancy. Acta Physiol. Plant.. 11:117-123.

Beaver, R.J. and J.A. Mosjidis. 1988. Important considerations in the analysis of generation means. Euphytica 39:233-235

Bigras, F.J. and A.L. D'Aoust. 1993. Influence of photoperiod on shoot and root frost tolerance and bud phenology of white spruce seedlings. Can. J. For. Res. 23:219-228.

Billington, H.L. and J. Pelham. 1991. Genetic variation in the date of budburst in scottish birch populations: Implications for climate change. Funct. Ecol. 5:403-409.

Bradshaw, Jr., H.D. and R.F. Stettler. 1995. Molecular genetics of growth and development in Populus. IV. Mapping QTLs with large effects on growth, form, and phenology traits in a forest tree. Genetics 139:963-973.

Cannell, M.G.R. and R.I. Smith. 1983. Thermal-time, chill days and prediction of budburst in Picea sitchensis. J. Appl. Ecol. 20:951-963.

Caprio, J.M. and H.A. Quamme. 1999. Weather conditions association with apple production in the Okanagan Valley of British Columbia. Can. J. Plant Sci. 79:129-137.

Champagnat, P. 1989. Rest and activity in vegetative buds of trees. Annales des Sciences Forestieres 46 (suppl.):9-26.

Chandler, W.H. and W.P. Tufts. 1934. Influence of the rest period on opening of buds of fruit trees in spring and on development of flower buds of peach trees. Proc. Amer. Soc. Hort. Sci. 30:180-186.

Charest, P.J., Y. Devantier, C. Jones, J.C. Sellmer, B.H. McCown, and D.D Ellis. 1997. Direct gene transfer in poplar, p. 60-64. In: N.B. Klopfenstein, Y.W. Chun, S.-S. Kim, and M.R. Ahuja (eds.). Micropropagation, genetic engineering, and molecular biology of Populus. U.S. Dept. Agr. For. Serv. Gen. Tech. Rpt. RM-GTR-297.

Close, T.J. 1997. Dehydrins: A commonalty in the response of plants to dehydration and low temperatures. Physiol. Plant. 100:291-296.

Conner, P.J., S.K. Brown, and N.F. Weeden. 1998. Molecular-marker analysis of quantitative traits for growth and development in juvenile apple trees. Theor. Appl. Genet. 96:1027-1035.

Crabbé, J. 1994. Dormancy, p. 597-611. In: Encyclopedia of agricultural science. vol. 1

Crabbé, J. and P. Barnola. 1996. A new conceptual approach to bud dormancy in woody plants, p. 83-113. In: G.A. Lang (ed.). Plant dormancy, physiology, biochemistry and molecular biology. CAB Intl., Wallingford, U.K

De FaY, E., V. Vacher, and F. Humbert. 2000. Water-related phenomena in winter buds and twigs of Picea abies L. (Karst.) until bud-burst: A biological, histological and NMR study. Ann. Bot. 86:1097-1107.

Dennis, F.G. 1987. Two methods for studying rest: Temperature alternation and genetic analysis. HortScience 22:820-824

Dennis, F.G. and L.J. Edgerton. 1961. The relationship between an inhibitor and rest in peach flower buds. Amer. Soc. Hort. Sci. 77:107-116.

Denney, F.E. and E.N. Stanton. 1928. Localization of response of woody tissues to chemical treatments that break the rest period. Amer. J. Bot. 15:337-344.

Doorenbos, J. 1953. Review of the literature on dormancy in buds of woody plants. Meded. Landbouwhogeschool Wageningen 53:1-24.

Dumbroff, E.B., D.B. Cohen, and D.P. Webb. 1979. Seasonal levels of abscisic acid in buds and stems of Acer saccharum. Physiol. Plant. 45:211-214.

Eagles, C.G. and P.F. Wareing. 1963. Dormancy regulators in woody plants. Nature 199:874-875.

Erez, A and S. Lavee. 1974. Recent advances in breaking the dormancy of deciduous fruit trees. Proc. 19th Intl. Hort. Congress Warsaw 3:69-78.

Erez, A. 1987. Chemical control of budbreak. HortScience 22:1240-1243.

Erez,A. and G.A. Couvillon. 1986. A characterization of the influence of moderate temperatures on rest completion in the peach. J. Amer. Soc. Hort. Sci. 112:677-680.

Erez, A. and S. Lavee. 1971. The effect of climatic conditions on dormancy development of peach buds. I. Temperature. J. Amer. Soc. Hort. Sci. 96 711-714.

Erez, A., G.A. Couvillon, and C.H. Hendershott. 1979. Quantitative chilling enhancement and negation in peach buds by high temperatures in a daily cycle. J. Amer. Soc. Hort. Sci. 104:536-540.

Erez, A., M. Faust, and M.J. Line. 1998. Changes in water status in peach buds on induction, development and release from dormancy. Scientia Hort. 73: $111-123$.

Erez, A., S. Lavee, and R.M. Samish. 1971. Improved methods for breaking rest in peach and other deciduous fruit species. J. Amer. Soc. Hort. Sci. 96:519-522.

Eriksson, G., I. Ekberg, I. Dormling, B. Matérn and D. von Wettstein. 1978.
Inheritance of bud-set and bud-flushing in Picea abies (L.) Karst. Theor. Appl. Genet. 52:3-19.

Eriksson, M.E. 2000. The role of phytochrome A and gibberellins in growth under long and short day conditions: Studies in hybrid aspen. $\mathrm{PhD}$ thesis. Swedish Univ. Ag. Sci., Umeå.

Farmer, Jr., R.E. and R.W. Reinholt. 1986. Genetic variation in dormancy relations of balsam poplar along a latitudinal transect in northwestern Ontario. Silvae Genet. 35:38-42.

Faust, M., A. Erez, L.J. Rowland, S.Y. Wang, and H.A. Norman. 1997. Bud dormancy in perennial fruit trees: Physiological basis for dormancy induction, maintenance and release. HortScience 32:623-629.

Faust, M. and S.Y. Wang. 1993. Biochemical events associated with resumption of growth in temperate zone fruit trees. Acta Hort.329:257-264.

Faust, M., D. Liu, M.M. Millard, and G.W. Stutte. 1991. Bound versus free water in dormant apple buds - A theory for endodormancy. HortScience 26:887-890.

Fennel, A. and E. Hoover. 1991. Photoperiod influences growth, bud dormancy and cold acclimation in Vitis labruscana and V. riparia. J. Amer. Soc. Hort. Sci. 116:270-273.

Fennell, A. and M.J. Line. 2001. Identifying differential tissue response in grape (Vitis riparia) during induction of endodormancy using nuclear magnetic resonance imaging. J. Amer. Soc. Hort. Sci. 126:681-688.

Fennell, A., C. Wake, and P. Molitor. 1996. Use of 1H-NMR to determine grape bud water state during the photoperiodic induction of dormancy. J. Amer. Soc. Hort. Sci. 121:1112-1116.

Fernandez-Escobar, R. and R. Martin. 1987. Chemical treatments for breaking rest in peach in relation to accumulated chilling. J. Hort. Sci. 62:457-461.

Fillatti, J.J., J. Sellmer, B. McCown, B. Haissig, and L. Comai. 1987. Agrobacterium mediated transformation and regeneration of Populus. Mol. Gen. Genet. 206:192-199.

Frankie, G.W., H.G. Baker. and P.A. Opler. 1974. Comparative phenological studies of trees in tropical wet and dry forests in the lowlands of Costa Rica. J. Ecol. 62:881-919.

Freundl, E., E. Steudle and W. Hartung. 1998.Water uptake by roots of maize and sunflower affects the radial transport of abscisic acid and its concentration in the xylem. Planta 207:8-19.

Freundl,E.,E. Steudle, and W. Hartung. 2000. Apoplastic transport of abscisic acid through roots of maize: Effect of the exodermis. Planta 210:222-231.

Frewen, B.E., T.H.H. Chen, G.T. Howe, J. Davis, A. Rohde, W. Boerjan, and H.D. Bradshaw, Jr. 2000. Quantitative trait loci and candidate gene mapping of bud set and bud flush in Populus. Genetics 154:837-845.

Fuchigami,L.H. and C-C.Nee. 1987. Degree growth stage model and rest breaking mechanisms in temperate woody perennials. HortScience 22:836-844.

Fuchigami, L.H. and M.E. Wisniewski. 1997. Quantifying bud dormancy: Physiological approaches. HortScience 32:618-623.

Fuchigami, L.H. C.J. Weiser, and D.R. Evert. 1971. Induction of cold acclimation in Cornus stolonifera. Plant Physiol. 47:98-103.

Fuchigami, L.H., C.J. Weiser, K. Kobayashi, R. Timmis, and L.V.Gusta. 1982. A degree growth stage (oGS) model and cold acclimation in temperate woody plants, p. 93-116. In: P.H. Li and A. Sakai (eds.). Plant cold hardiness and freezing stress. Academic Press, New York.

Galletta, G.J. and J.R. Ballington. 1996. Blueberries, cranberries, and lingonberries, p. 1-107. In: J. Janick and J.N. Moore (eds.). Fruit breeding. vol. 2. Wiley, New York

Gardea, A.A., L.S. Daley, R.L. Kohnert, A.H. Soeldner, L. Ning, P.B. Lombard, and A.N. Azarenko. 1994. Proton NMR signals associated with eco- and endodormancy in vinegrape buds. Sci. Hort. 56:339-358.

Gévaudant, F., G. Pétel, and A. Guilliot. 2001. Differential expression of fou members of the $\mathrm{H}^{+}$-ATPase gene family during dormancy of vegetative buds of peach trees. Planta 212:619-626.

Grossmann, K. and H. Hansen. 2001. Ethylene-triggered abscisic acid: A principle in plant growth regulation? Physiol. Plant. 113:9-14.

Guy, C.L. 1990. Cold acclimation and freezing stress tolerance: Role of protein metabolism. Annu Rev. Plant Physiol. Plant Mol. Biol. 41:187-223.

Hancock, J.F. and A.D. Draper. 1989. Blueberry culture in North America. HortScience 24:551-556.

Hancock, J.F., W.A. Erb, B.L. Goulart, and J.C. Scheerens. 1995. Utilization of wild blueberry germplasm: The legacy of Arlen Draper. J. Small Fruit Viticult. 3:1-16

Hänninen, H. 1995. Effects of climatic change on trees from cool and temperate regions: An ecophysiological approach to modeling bud burst phenology. Can. J. Bot. 73:183-199.

Hansche, P.E. 1990. Heritability of spring bloom and fall leaf abscission dates in Prunus persica. HortScience 25:1639-1641.

Hardie, D.G. 1994. Ways of coping with stress. Nature 370:599-600.

Hauagge, R. and J.N. Cummins. 1991. Genetics of length of dormancy period in Malus vegetative buds. J. Amer. Soc. Hort. Sci. 116:121-126.

Heide, O.M. 1974. Growth and dormancy in Norway spruce ecotypes (Picea ab- 
ies) I. Interaction of photoperiod and temperature. Physiol Plant. 30:1-12. Hemberg, T. 1949. Growth-inhibiting substances in terminal buds of Fraxinus. Physiol. Plant. 2:37-44.

Hocking, T.J. and J.R. Hillman. 1975. Studies on the role of abscisic acid in the initiation of bud dormancy in Alnus glutinosa and Betula pubescens. Planta 125:235-242.

Honjo, H., Y. Kobayashi, M. Watanabe, R. Fukui, and T. Sugiura. 2002. A new approach to controlling the flowering date for japanese pear using reflective film technique. Acta Hort. 2(587):389-396.

Howe, G.T., J. Davis, Z. Jeknic, T.H.H. Chen, B. Frewen, H.D. Bradshaw, Jr., and P. Saruul. 1999. Physiological and genetic approaches to studying endodormancy-related traits in Populus. HortScience 34:1174-1184.

Howe, G.T., P. Saruul, J. Davis, and T.H.H. Chen. 2000. Quantitative genetics of bud phenology, frost damage, and winter survival in an F2 family of hybrid poplars. Theor. Appl. Genet. 101:632-642.

Howell, Jr., G.S. and C.J. Weiser. 1970. The environmental control of cold acclimation in apple. Plant Physiol. 45:390-394.

Hummel, R.C. P.D. Ascher, and H.M. Pellett. 1982. Inheritance of the photoperiodically induced cold acclimation response in Cornus sericea. Theor Appl. Genet. 62:385-394.

Iwahori, S, H. Gemma, K. Tanabe, A.D. Webster, and A.G. White. 2002. Proceedings of the international symposium on asian pears commemorating the 100th anniversary of 'Nijisseiki' pear. Acta Hort. (587).

Iwasaki, K. and R.J. Weaver. 1977. Effects of chilling, calcium cyan amide, and bud scale removal on budbreak, rooting, and inhibitor content of buds of 'Zinfandel' grape (Vitis vinifera). J. Amer. Soc. Hort. Sci. 102:584-587.

Janick, J. and J.N. Moore, eds. 1975. Advances in fruit breeding. Purdue University Press, West Lafayette, Ind.

Jermstad, K.D., D.L. Bassoni, K.S. Jech, N.C. Wheeler, and D.B. Neale. 2001 Mapping of quantitative trait loci controlling adaptive traits in coastal douglasfir. I. Timing of vegetative bud flush. Theor. Appl. Genet. 102:1142-1151.

Jian, L-C., P.H. Li, L-H Sun, and T.H.H. Chen. 1997. Alterations in ultrastructure and subcellular localization of $\mathrm{Ca}^{2+}$ in poplar apical cells during the induction of dormancy. J. Expt. Bot. 48:1195-1207.

Junttila, O. 1980. Effect of photoperiod and temperature on apical growth cessation in two ecotypes of Salix and Betula. Physiol. Plant. 48:347-352.

Junttila, O. 1982. The cessation of apical growth in latitudinal ecotypes and ecotype crosses of Salix pentandra L. J. Expt. Bot. 33:1021-1029.

Junttila, O. 1990. Gibberellins and the regulation of shoot elongation in woody plants, p. 199-210. In: N. Takahashi, B.O. Phinney, and J. MacMillan (eds.) Gibberellins. Springer-Verlag, Berlin.

Karssen, C.M., D.L.C. Brinkhorst-van der Swan,A.E. Breekland, and M. Koornneef. 1983. Induction of dormancy during seed development by endogenous abscisic acid: Studies on abscisic acid deficient genotypes of Arabidopsis thaliana. Planta 157:158-165.

Kaurin, A., O. Junttila, and J. Nilsen. 1985. Plant production in the north: Proceedings, plant adaptation workshop. Norwegian Univ. Press, Norway.

Koussa, T., D. Zaoui, and M. Broquedis. 1998. Relationship between the levels of abscisic acid in latent buds, in leaves and in internodes of Vitis vinifera cv. Merlot during the dormancy phase. J. International des Sciences de la Vigne et du Vin 32:203-210.

Lang, A. 1957. The effect of gibberellin upon flower formation. Proc. Natl. Acad. Sci. USA 43:709-711.

Lang, G.A. (ed.). 1996. Plant dormancy: Physiology, biochemistry, and molecular biology. CAB Intl., Oxford.

Lang, G.A. 1987. Dormancy: A new universal terminology. HortScience 22: 817-820.

Lang, G.A. 1994. Dormancy - The missing links: Molecular studies and integration of regulatory plan and regulatory plant and environmental interactions. HortScience 29:1255-1263.

Laufs, P., C. Jonak, and J. Traas. 1998. Cells and domains: Two views of the shoot meristem in Arabidopsis. Plant Physiol. Biochem. 36:33-45.

Lawson, D.M., M. Hemmat, and N.F. Weeden. 1995. The use of molecular markers to analyze the inheritance of morphological and developmental traits in apple. J. Amer. Soc. Hort. Sci. 120:532-537.

Leike, H. 1965. Neuere Ergebnisse über die Ruheperiode (Dormancy) der Gehölzknospen. Wiss. Z. Univ. Rostock, Math.-naturwiss. R. 14:475-492.

Lenton, J.R., V.M. Perry, and P.F. Saunders. 1972. Endogenous abscisic acid in relation to photoperiodically induced bud dormancy. Planta. 106:13-22.

Leubner-Metzger, G., C. Fründt, and F. Meins Jr. 1996. Effects of gibberellins, darkness and osmotica on endosperm rupture and class I $\beta$-1,3-glucanase induction in tobacco seed germination. Planta 199:282-288.

Levitt, J. 1980. Plant responses to environmental stresses. vol I. Academic Press, New York.

Linden, L. 2001. Re-analyzing historical records of winter injury in Finnish apple orchards. Can. J. Plant Sci. 81:479-485.

MacDonald, J.E. and J.N. Owens. 1993. Bud development in coastal douglasfir seedlings in response to different dormancy-induction treatments. Can.
J. Bot. 71:1280-1290

MacDonald, J.E.. 2000. The developmental basis of bud dormancy in 1-year-old Picea and Pseudostuga seedlings. In: J.-D. Viemont and J. Crabbe (eds.). Dormancy in plants. CABI Publ., New York.

Mather, S.K. and J.L. Jinks. 1982. Biometrical genetics: The study of continuous variation. 3rd ed. Chapman and Hall, London.

Maurel, C. 1997. Aquaporins and water permeability of plant membranes. Annu. Rev. Plant Physiol. Plant Mol. Biol. 48:399-429.

Menzel, A. and P. Fabian. 1999. Growing season extended in Europe. Nature 397:659.

Moore, J.N. and J. Janick (eds.). 1983. Methods in fruit breeding. Purdue Univ. Press, West Lafayette, Ind.

Müller-Thurgau, H. 1885. Beitrag zur Erklärung der Ruheperioden der Pflanzen. Landw. Jahrb. 14:851-907

Nir, G., Y. Shulman, L. Fanberstein, and S. Lavee. 1986. Changes in the activity of catalase in relation to the dormancy of grapevine (Vitis vinifera) buds. Plant Physiol. 81:1140-1142.

Nissila, P.C. and L.H. Fuchigami. 1978. The relationship between vegetative maturity and the first stage of cold acclimation. J. Amer. Soc. Hort. Sci. 103:710-711.

Nitsch, J.P. 1957. Growth responses of woody plants to photoperiodic stimuli. Proc. Amer. Soc. Hort. Sci. 70:512-525.

Nooden, L.D. and J.A. Weber. 1978. Environmental and hormonal control of dormancy in terminal buds in plants, p. 221-226. In: M.E. Clutter (ed.). Dormancy and developmental arrest. Academic Press, New York.

Okubo, H. 2000. Growth cycle and dormancy in plants. In: J.-D. Viemont and J. Crabbe (eds.). Dormancy in plants. CABI Publ., New York.

Olsen, J.E., O. Junttila, J. Nilsen, M.E. Eriksson, I. Martinussen, O. Olsson, G. Sandberg, and T. Moritz. 1997. Ectopic expression of oat phytochrome A in hybrid aspen changes critical daylength for growth and prevents cold acclimatization. Plant J. 12:1339-1350.

Oppenheimer, C.H. and E. Slor. 1968. Breeding of apples for a subtropical climate. II. Analysis of two F2 and nine backcross populations. Theor. Appl. Genet. 38:97-102.

Or, E., I. Vilozny, A. Fennell, Y. Eyal, and A. Ogrodvitch. 2002. Dormancy in grape buds: Isolation and characterization of catalase cDNA and analysis of its expression following chemical induction of bud dormancy release. Plant Sci. 162:121-130.

Or, E., I. Vilozny, Y. Eyal, and A. Ogrodvitch. 2000. The transduction of the signal for grape dormancy breaking, induced by hydrogen cyanamide, may involve the SNF-like protein kinase GDBrPK. Plant Mol. Biol. 43:483-489.

Owens, J.N. and M. Molder. 1973. A study of DNA and mitotic activity in the vegetative apex of douglas fir during the annual growth cycle. Can. J. Bot. 51:1395-1409.

Parmentier, C.M., L.J. Rowland. and M.J. Line. 1998. Water status in relation to maintenance and release from dormancy in blueberry flower buds. J. Amer. Soc. Hort. Sci. 123:762-769.

Perry, T.O. 1971. Dormancy of trees in winter. Science 171:29-36.

Phillips, I.D., and P.F. Wareing. 1958. Studies in dormancy of sycamore. I. Seasonal changes in the growth-substance content of the shoot. J. Expt. Bot. 9:350-364. Plant Sci. 126:119-144.

Powell, L.E. 1987. Hormonal aspects of bud and seed dormancy in temperatezone woody plants. HortScience 22:845-850.

Purvis, O.N. 1961. The physiological analysis of vernalization. Encycl. Plant Physiol. 16:76-122.

Quamme, H.A., W.A. Su, and L.J. Veto. 1995. Anatomical features facilitating supercooling of the flower within the dormant peach flower bud. J. Amer. Soc. Hort. Sci.120:814-822.

Rehfeldt, G.E. 1977. Growth and cold hardiness of intervarietal hybrids of douglas-fir. Theor. Appl. Genet. 50:3-15.

Rinne, P., A. Saarelainen, and O. Junttila. 1994a. Growth cessation and bud dormancy in relation to ABA level in seedlings and coppice shoots of Betula pubescens as affected by a short photoperiod, water stress and chilling. Physiol. Plant. 90:451-458.

Rinne, P.,A. Welling, and P. Kaikuranta. 1998. Onset of freezing tolerance in birch Betula pubescens involves LEA proteins and osmoregulation and is impaired in an ABA-deficient genotype. Plant, Cell and Environ. 21:601-611.

Rinne, P., H. Hänninen, P. Kaikuranta, J.E. Jalonen, and T. Repo. 1997. Freezing exposure releases bud dormancy in Betula pubescens and B. pendula. Plant, Cell and Environ. 20:1199-1204.

Rinne, P., H. Tuominen, and O. Junttila. 1994b. Seasonal changes in bud dormancy in relation to bud morphology, water and starch content, and abscisic acid concentration in adult trees of Betula pubescens. Tree Physiol. 14:549-561.

Rinne, P.L.H. and C. van der Schoot. 1998. Symplasmic fields in the tunica of the shoot apical meristem coordinate morphogenetic events. Development 125:1477-1485

Rinne, P.L.H., P.M. Kaikuranta, and C. van der Schoot. 2001. The shoot api- 
cal meristem restores its symplasmic organization during chilling-induced release from dormancy. Plant J. 26:249-264.

Rodriguez-A, J., W.B. Sherman, R. Scorza, M. Wisniewski, and W.R. Okie. 1994. 'Evergreen' peach, its inheritance and dormant behavior. J. Amer. Soc. Hort. Sci. 119:789-792.

Rohde, A., M. Van Montagu, D. Inze, and W. Boerjan. 1997. Factors regulating the expression of cell cycle genes in individual buds of Populus. Planta 201:43-52.

Romberger, J.A. 1963. Meristems, growth, and development in woody plants. Forest Serv. Tech. Bul. 1293. USDA.

Rowland, L.J., A. Levi, R. Arora, E.L. Ogden, M.M. Muthalif, N. Vorsa, R.G. Novy, and M.E. Wisniewski. 1995. Progress toward identifying markers linked to genes controlling chilling requirement and cold hardiness in blueberry. J. Small Fruit Viticult. 3:39-52.

Rowland, L.J. and R. Arora. 1997. Proteins related to endodormancy (rest) in woody perennials. Plant Sci. 126:119-144.

Rowland, L.J., E.L. Ogden, R. Arora, C-C. Lim, J.S. Lehman, A. Levi, and G.R. Panta. 1999. Use of blueberry to study genetic control of chilling requirement and cold hardiness in woody perennials. HortScience 34:1185-1191.

Rowland, L.J., S. Mehra, A. Dhanaraj, E.L. Ogden, and R. Arora. 2003. Identification of molecular markers associated with cold tolerance in blueberry. Acta Hort. (in press).

Sakai, A. 1979. Freeezing avoidance mechanism in primordial shoots of conifer buds. Plant Cell Physiol. 20:1381-1390.

Salzman, R.A., R.A. Bressan, P.M. Hasegawa, E.N. Ashworth, and B.P. Bordelon 1996. Programmed accumulation of LEA-like proteins during desiccation and cold acclimation of overwintering grape buds. Plant Cell Environ. 19: 713-720.

Samish, R.M. 1954. Dormancy in woody plants. Annu. Rev. Plant Physiol. 5: 183-203.

Saunders, P. 1978. Phytohormones and bud dormancy, p. 423-445. In: D.S Letham, P.B. Goodwin, and T.J.V. Higgins (eds.). Phytohormones and related compounds·a comprehensive treatise. Elsevier, North Holland.

Saure, M.C. 1985. Dormancy release in deciduous fruit trees. Hort. Rev. 7: 239-300

Sauter, A., W.J. Davies, and W. Hartung. 2001. The long-distance abscisic acid signal in the droughted plant: The fate of the hormone on its way from root to shoot. J. Expt. Bot. 52:1991-1997.

Seeley, S.D. 1996. Modelling climatic regulation of bud dormancy, p. 361-376. In: G.A. Lang (ed.). Plant dormancy: Physiology, biochemistry and molecular biology. CAB Intl., Wallingford, U.K.

Sharp, R.E., M.E. LeNoble, M.A. Else, E.T. Thorne, and F. Gherardi. 2000 Endogenous ABA maintains shoot growth in tomato independently of effects on plant water balance: Evidence for an interaction with ethylene. J. Expt. Bot. 51:1575-1584.

Shepherd, V.A. and P.B. Goodwin. 1992. Seasonal patterns of cell-to-cell communication in Chara corallina. II. Cell-to-cell communication in vegetative lateral branches during winter and spring. Plant Cell Environ. 15:137-150.

Shirazi, A.M. and L.H. Fuchigami. 1995. Effects of 'near-lethal' stress on bud dormancy and stem cold hardiness in red-osier dogwood. Tree Physiol 15:275-279.

Siller-Cepeda, J.H., L.H. Fuchigami, and T.H.H. Chen. 1992. Hydrogen cyanamideinduced budbreak and phytotoxicity in 'Redhaven' peach buds HortScience 27:874-876.

Simpson, G.M. 1990. Seed dormancy in grasses. Cambridge Univ. Press, Cambridge.

Stevenson, R.K. 1994. Dormancy and acclimation in dogwood clonal ecotypes. MS thesis. Univ. Saskatchewan, Saskatoon.

Strauss, M., F. Kauder, M. Peisker, U. Sonnewald, U. Conrad, and D. Heineke. 2001. Expression of an abscisic acid-binding single-chain antibody influences the subcellular distribution of abscisic acid and leads to developmental changes in transgenic potato plants. Planta 213:361-369.

Sugiura, T., H. Kuroda, H. Honjo, and D. Ito. 2002. Temperature dependence of endodormancy development in flower buds of 'Kousui' japanese pear and a model for estimating the completion of endodormancy. Acta Hort 2(587):345-352.

Svendsen, E.I. 2003. A molecular approach for studying vegetative maturity in red-osier dogwood (Cornus sericea) MS thesis. Univ. of Saskatchewan, Saskatoon, SK.

Tamura, F., K. Tanabe, A. Itai. 2002. Regulation of endodormancy in japanese pear. Acta Hort. 2 (587):325-336.

Tamura, F., K. Tanabe, A. Itai, and H. Tanaka. 1998. Protein changes in the flower buds of japanese pear during breaking of dormancy by chilling or high-temperature treatment. J. Amer. Soc. Hort. Sci. 123:532-536.

Tamura, F., K. Tanabe, and T. Ikeda. 1993. Relationship between intensity of bud dormancy and level of ABA in japanese pear 'Nijisseiki'. J. Jpn. Soc. Hort. Sci. 62:75-81.

Tanino, K.K., L.H. Fuchigami, T.H.H. Chen, L.V. Gusta, and C.J. Weiser. 1989 Dormancy-breaking agents on acclimation and deacclimation of dogwood. HortScience 24:353-354.

Tanksley, S.D. and J. Hewitt. 1988. Use of molecular markers in breeding for soluble solids content in tomato-A re-examination. Theor. Appl. Genet. 75:811-823.

Tanksley, S.D., N.D. Young, A.H. Paterson, and M.W. Bonierbale. 1989. RFLP mapping in plant breeding: New tools for an old science. Bio/Technology 7:257-264.

Thomas, A., A.D. Tomos, J.L. Stoddart, H. Thomas, and C.J. Pollock. 1988 Cell expansion, temperature and turgor pressure in growing leaves of Lolium temulentum. New Phytologist 112:1-5.

Thompson, M.M., D.C. Smith, and J.E. Burgess. 1985. Nondormant mutants in a temperate tree species, Corylus avellana L. Theor. Appl. Genet. 70: 687-692.

Tung, C.-H and D.R. Deyoe. 1991. Dormancy induction in container-grown Abies seedlings: Effects of environmental cues and seedling age. New For. 5:13-22.

van der Schoot, C. 1996. Dormancy and symplasmic networking at the shoo apical meristem, p. 59-81. In: G.A. Lang (ed.). Plant dormancy: Physiology, biochemistry, and molecular biology. CAB Intl., Wallingford, U.K.

van Huystee, R.B., C.J. Weiser, and P.H. Li. 1967. Cold acclimation in Cornus stolonifera under natural and controlled photoperiod and temperature. Bot. Gaz. 128:200-205.

Vegis, A. 1964. Dormancy in higher plants. Annu. Rev. Plant Physiol. 15: $185-224$

Viémont, J.-D. and J. Crabbé (eds.). 2000. Dormancy in plants: From whole plant behavior to cellular control. CAB Intl., Oxford.

Wang, S.Y., H.J. Jiao, and M. Faust. 1991. Changes in metabolic enzyme activities during thidiazuron-induced lateral budbreak of apple. HortScience 26:171-173

Wang, S.Y. and M. Faust. 1988. Metabolic activities during dormancy and blooming of deciduous fruit trees. Israel J. Bot. 37:227-243.

Wareing, P.F. 1956. Photoperiodism in woody plants. Annu. Rev. Plant Physiol. 7:191-214.

Wareing, P.F. 1969. The control of bud dormancy in seed plants. Symp. Soc. Expt. Biol. 23:241-262.

Weinberger, J.H. 1950. Chilling requirements of peach varieties. Proc. Amer. Soc. Hort. Sci. 56:122-128.

Weiser, C.J. 1970. Cold resistance and injury in woody plants. Science 169: 1269-1278.

Welling, A., P. Kaikuranta and P. Rinne. 1997. Photoperiodic induction of dormancy and freezing tolerance in Betula pubescens. Involvement of ABA and dehydrins. Physiol. Plant. 100:119-125.

Whitelam, G.C. and P. Devlin. 1997. Roles of different phytochromes in Arabidopsis photomorphogenesis. Plant Cell Env. 20:752-758.

Wilen, R.W., P.F. Fu, A.J. Robertson, S.R. Abrams, N.H. Low, and L.V. Gusta 1996. An abscisic acid analog inhibits abscisic acid-induced freezing tolerance and protein accumulation, but not abscisic acid-induced sucrose uptake in a bromegrass (Bromus inermis Leyss) cell culture. Planta 198:138-143.

Wisniewski, M.E., S. J. Sauter, L.H. Fuchigami, and V. Stepien. 1997. Effects of near-lethal heat stress on budbreak, heat shock proteins and ubiquitin in dormant poplar (Populus nigra Charkowiensis $\mathrm{x}$ P. nigra incrassata). Tree Physiol. 17:453-460.

Wood, B.W. 1993. Hydrogen cyanamide advances pecan budbreak and harvesting. J. Amer. Soc. Hort. Sci. 118:690-693.

Worrall, J. and F. Mergen. 1967. Environmental and genetic control of dormancy in Picea abies. Physiol. Plant. 20:733-745. 